\title{
Introduction of "Green" Technologies in a Modern City
}

\author{
Антон Назаров ${ }^{1, *}$, Денис Ковтун ${ }^{1}$, and Stefan Talu $^{2}$ \\ ${ }^{1}$ Ural State University of Economics, 620000 Yekaterinburg, Russia \\ ${ }^{2}$ The Technical University of Cluj-Napoca, 400114 Cluj-Napoca, Romania
}

\begin{abstract}
The rate of improvement in the comfort of the modern urban environment significantly reduces the negative factors, arising from violations of the ecological balance of the environment: pollution of air, soil, water, depletion of the ozone layer. One of the most important problems of the modern world is the ecology of the urban environment. The article considers the factors, that negatively affect living and nonliving natural objects of cities. Green innovative technologies are analyzed, through which people strive to restore the environment - air, water, soil. Measures are proposed to improve the efficiency of the application of green technologies.
\end{abstract}

\section{Introduction}

Huge harm to the environment in the territories of cities is caused by: a) enterprises, that mine and process valuable minerals (destroy, pollute the soil with waste; cause enormous damage to groundwater); b) energy enterprises, operating on fuel, that pollutes the air; c) enterprises with outdated production technologies (poorly recycled waste pollute air, water, soil); d) transport (the main air pollutant) [7].

Harmful substances, arising from the combustion of fuel and the destruction of forests, pollute the air, causing a significant increase in the concentration of carbon dioxide in it. Dangerous emissions of sulfur dioxide (the result of fuel combustion at Heat power plants), nitrogen oxides, emitted by car exhaust, solid pollutants (dust, soot). In many cities of our country, the maximum permissible concentration of air pollution is exceeded by 5-10 times.

Air polluting elements fall on the ground in the form of acid rain, deteriorating the composition of the soil. Household waste, solid and liquid substances, formed as a result of agricultural, industrial activity of people, and the functioning of transport, also cause huge damage to the topsoil. Especially dangerous are heavy metals, which do not decompose, but only go from one form to another, as well as oil refined products and pesticides, that penetrate from soil into plants and water. As a result, many plants cannot adapt to changes in the chemical composition of the soil, stop bearing fruit, mutate and die [2].

\footnotetext{
*Corresponding author: nazarovad@usue.ru
} 


\section{Materials and Methods}

The water is now heavily polluted by oil products, that enter the oceans due to the collapse of tankers, constant wastewater discharges from factories and plants.

Agriculture, industrial and household enterprises strongly pollute the hydrosphere with organic compounds and heavy metals.

The ozone layer is destroyed by chlorofluorocarbons, contained in refrigerants, air conditioners, solvents, aerosols, fire extinguishers, as well as jet flights in the atmosphere, nuclear weapons tests, and a decrease in the Earth's forest fund.

All of listed factors negatively affect the health of people, especially the population of cities, where a lot of industrial, domestic, transport facilities are concentrated. Air pollution leads to diseases of the bronchi and lungs. Food, based on unhealthy plant and animal raw materials, causes general organism dysfunction. Chemicals, dissolved in water, cause disturbances in intracellular metabolism, the functioning of the cardiovascular system, and kidneys. The destruction of a thin strip of the stratosphere, that protects life on our planet from solar ultraviolet radiation, entails a weakening of the immune system, dangerous diseases of the skin and eyes [6].

\section{Findings and Discussion}

The causes of ecological problems are, first of all, the careless attitude of people towards living and non-living objects of nature, the application of outdated technologies for the use of biological resources. Therefore, overcoming the ecological crisis in order to protect and preserve the environment is becoming one of the most important tasks of the state, which guarantees its citizens a steady growth in prosperity, level and comfort of life.

Already now, low-waste and low-toxic ecological technologies are being actively introduced into the development of the world economy. To preserve the environment of modern cities, a policy of rational use of natural resources is being implemented: reduction of pollution of water, air, soil; effective waste management; generation of energy from alternative (renewable) sources; construction of energy efficient buildings, installation of household appliances, that allow the rational use of energy resources; prevention of production toxicity.

In almost all spheres of life of the population of cities, ecological technologies are being introduced [4]:

- enterprises are put into operation with recycling and re-production of products;

- due to innovations in the consumption structure, waste is reduced;

- harmful industries are modified, replaced by harmless ones by using natural technologies;

- renewable sources of raw materials and energy take place of non-renewable resources;

- science is looking for ways to create safe food, maximum purification of drinking water;

- "green" transport and "green" construction are developing. 


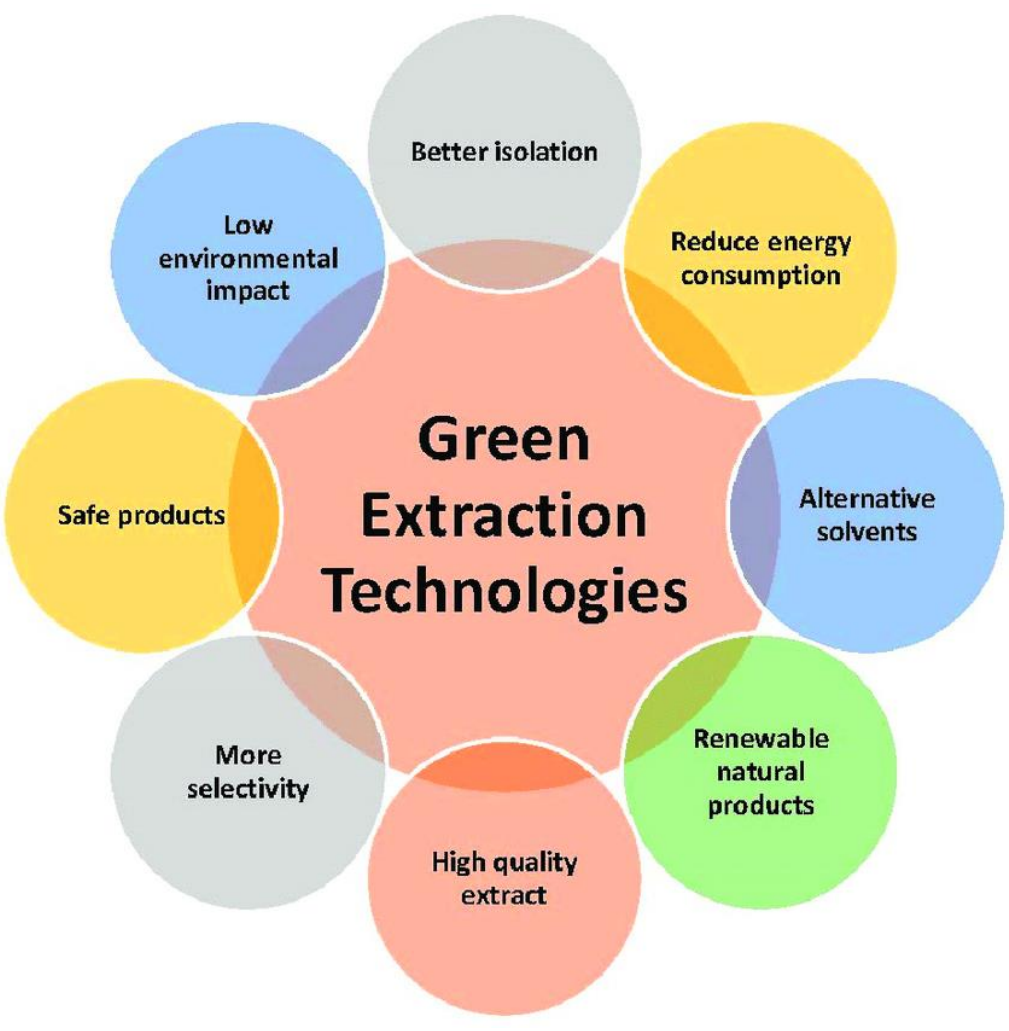

Fig. 1. Advantages of the use of green technologies.

The key aspect of the development of "green" technologies to improve the quality of life in cities is the ecologization of the energy sector, that is, the introduction of innovative alternative energy sources, improvement of the energy efficiency of all structures and spheres.

A huge contribution to the sustainable provision of the population of cities with energy is made by: hydroelectric dams, nuclear power plants, devices, through which the energy of the sun, water, wind, geological activity of the earth crust, tides, fuels, generated from plants and such biological sources as ethanol, glucose, algae, fungi, bacteria, energy from processes, involving hydrogen gas.

The active development of alternative energy sources is facilitated by the energy crisis, caused by the limited availability of fossil fuels, that is, the lack of natural hydrocarbons and environmental pollution, an imbalance in the interrelations between man and nature [1].

At present, the cost of installing wind and solar power plants has decreased several times, therefore, their capabilities can be used more widely, receiving electricity for residential and office buildings, unmanned aerial vehicles, electric vehicles, and various electronics.

The American researcher Uribe-Romo created a synthetic material, that, under the influence of photons of light, turns carbon dioxide into fuel. In addition to generation of ecologically friendly fuel, the invention significantly reduces the amount of greenhouse gas, harmful to the atmosphere, and helps to save precious metals, which are simply not needed: titanium is used for chemical processes. It costs hundreds of times less than platinum and iridium. 
Biofuel, generated from algae, is very economical: it is produced directly in algae using the energy of the sun. The fuel production process does not harm the environment.

Scientists from the US state of California are close to creating an alternative to an electric battery, based on champignons, stating, that the capacity of the batteries will be increasing over time, and not decrease due to the high porosity of the mushrooms and the content of large amounts of potassium salts in them.

One of the promising alternative fuels is hydrogen, which contains a lot of energy, but does not emit greenhouse gases when combusting. But the process of generating this fuel cannot be called ecologically friendly. In addition, large reserves of natural gas and coal are spent on it, which is quite expensive. British scientists invented an innovative method of producing hydrogen from fescue, that solves all of these problems. Works are also underway to produce hydrogen from cellulose by means of sunlight and a catalyst [3].

Green buildings have great opportunities to improve the urban environment by meeting ecological requirements for construction materials, energy and resource consumption, climate risk management, waste recycling, indoor air and lighting quality.

\section{Conclusions}

Integration of green ICT into the development strategy of modern cities will allow minimizing greenhouse gas emissions and ensuring energy savings. Experts recommend intensifying the introduction of the following technologies:

- virtualization and consolidation of systems, performing set, well-defined, variable sequences of operations: reducing the total electricity consumption;

- energy management of computers: increasing energy efficiency while reducing electricity consumption;

- remote presence at the workplace: reducing the consumption of motor fuel;

- disposal of office equipment: waste minimization;

- electronic document management: energy saving.

Effective ecological protection of cities can be ensured through the consistent introduction of green technologies, the implementation of a set of measures, including:

1. Ecological monitoring and assessment of the effects of human economic activity on the environment.

2. Creation of standards for emissions and discharges of pollutants into nature [5].

3 . The requirement of strict observance by all legal subjects of the laws, regulating the procedure for the use of natural resources in cities.

4. Ecological control, aimed at preventing violations of green legislation.

5. Ecological audit as a way of independent assessment of compliance by business entities with regulations, controlling public relations in the field of environmental management.

6. Protection of the natural environment from the negative impact of economic activity of people, man-made and natural disasters.

7. Ecological expertise to establish the compliance of the economic activity of urban residents with ecological standards.

8. Ecological insurance in case of natural disasters.

9. Establishment of fees for pollution of water, air, soil.

A competent local ecological policy, coordinated with the ecological strategy of the state, will allow to positively influence the environmental situation in the city, consistently restore the living environment, and steadily increase the level of comfort of citizens, their prosperity and health. 


\section{References}

1. B. B. Bogush, R.M. Khaziakhmetov, V. Bushuev et al. Energy Policy 1, 3 (2016)

2. P.A. Boev, D.L. Burenko, E.A. Schwartz, M. Wackernagel, A. Dieppe, L. Hanscom, K. Iha, R. Kelly, J. Martindill, G. Zokai, The Ecological Footprint of the Constituent Entities of the Russian Federation. Key findings and recommendations - World Wildlife Fund (WWF), 72 (2017)

3. I.V. Voitov, A.V. Neverov, Ch.A. Romanovsky, O. I. Rodkin, A.V. Ravino, A.I. Kavrus, Proceedings of BSTU. Economics and Management 7, 145 (2017)

4. M.V. Galushko, K.R. Sharipova, Creative Economy. 14(6), 1079 (2020)

5. Yu.S. Drugov, Analysis of contaminated soil and hazardous waste: monograph. (Knowledge Lab, 2019)

6. R.G. Mamin, Innovative Waste Management Mechanisms (MGSU, 2018)

7. O.S. Sausheva, Online Journal of Science of Science 8 (5 (36)), 50 (2016)

8. W. Basmi, A. Boulmakoul, L. Karim, A. Lbath, Procedia Computer Science 170, 43 (2020)

9. C. Benavente-Peces, N. Ibadah, Energies 13 (13), (2020)

10. A. Chehri, H.T. Mouftah, Sustainable Cities and Society, 51 (2019)

11. L. Herslund, P. Mguni, Sustainable Cities and Society, 48 (2019)

12. J. Kim, J. Kang, Sustainability (Switzerland) 13 (1), 1 (2021)

13. K. Kimic, G. Maksymiuk, M. Suchocka, Bulletin of Geography. 43(1), 121 (2019

14. Z. Mingaleva, N. Vukovic, I. Volkova, T. Salimova, Sustainability (Switzerland) 12 (1), 1 (2020)

15. H. D. Mohammadian, V. Wittberg, M. Castro, G. Bolandian, Proceedings of 2020 IEEE Learning with MOOCS, LWMOOCS 2020, 118 (2020).

16. T. Orlovskaya, S. Ershova, The study of the sociospatial aspect of green building in st.petersburg: Theoretical and practical aspects, E3S Web of Conferences, 135 (2019)

17. W. Shoman, M. Korkutan, U. Alganci, A. Tanik, H. Demirel, Fresenius Environmental Bulletin, 28(2), 688 (2019)

18. A. I. Stefanakis, Sustainability (Switzerland) 11(24), (2019)

19. Z. Ullah, F. Al-Turjman, L. Mostarda, P. Gagliardi, Computer Communications 154, 313 (2020)

20. L. Zhang, R. Long, H. Chen, Resources, Conservation and Recycling 142, 113 (2019) 